\title{
Induction of antinuclear antibodies by ultraviolet irradiation
}

\author{
J. H. TEN VEEN AND C. J. LUCAS \\ From the Central Laboratory of the Netherlands Red Cross Blood Transfusion Service and the Laboratory of \\ Immunopathology, University of Amsterdam, Amsterdam
}

Ultraviolet (UV) irradiation or exposure to sunlight are well known but poorly understood predisposing factors of systemic lupus erythematosus (SLE) (Dubois, 1966; Freeman, Knox, and Owens, 1969). It appears from the published literature, that little attention has been paid to what actually occurs when apparently healthy individuals are exposed to UV irradiation.

On a molecular level, UV irradiation of DNA is known to cause, among other things, dimerization of adjacent thymine groups in the DNA molecule (Setlow, 1968). Micro-organisms and also some species of higher animals possess enzymatic mechanisms which protect them against the influence of UV light (Setlow, 1968; Freeman, Troll, and Knox, 1968; Cleaver and Painter, 1968; Cook and Regan, 1969). One of these mechanisms is dependent on energy offered by light of longer wave-length than that of the damaging radiation. This process, which is called photoreactivation, splits the thymine dimers, thus restoring the original structure of the DNA molecule (Setlow, 1968).

Another consequence of UV irradiation of DNA is that the DNA molecule, which is normally a very weak antigen, becomes a strong one. After the injection of UV-irradiated DNA (UV-DNA) into rabbits, antibodies with high titres against UV-DNA are found (Levine, Seaman, Hammerschlag, and van Vunakis, 1966). We found that after prolonged immunization the sera of 6 rabbits cross-reacted with normal nonirradiated DNA, in low titres. When determined with a complement-fixation technique, the anti-UV-DNA titres varied between $1 / 512$ and $1 / 1024$ and the anti-DNA titres between $1 / 16$ and $1 / 64$. This strong antigenic ability of UV-DNA led us to investigate the effects of UV irradiation on mice. Since ther are indications that a photoreactivation-like process might exist in mice (Freeman and others, 1968), a model was chosen in which a possible influence of daylight could be observed.

\begin{abstract}
Material and methods
EXPERIMENTAL ANIMALS

In our first experiment (Fig. 1), twelve 16-week-old female Swiss mice were divided into three groups: A, B, and $\mathrm{C}$, and treated according to the following scheme: Group A mice were irradiated daily for 5 hours in the morning and afterwards placed in normal daylight, behind glass.

Group B mice received the same UV treatment, but were kept strictly in the dark after irradiation.

Group C mice served as untreated controls.
\end{abstract}

This experiment was repeated with 3 groups of 32 Swiss mice, each group consisting of 16 males and 16 females, aged 6 and 8 weeks respectively at the beginning of the experiment.

SOURCE OF UV LIGHT

UV irradiation was performed with a Philips Germicida lamp, type 57413, which emits predominantly UV light with a wave length of $253,7 \mathrm{~nm}$, placed $50 \mathrm{~cm}$. above the animals. During UV irradiation no other light could reach the mice.

\section{SERA}

After 2, 4, 6, and 8 weeks, blood was taken by orbital sinus puncture and examined for antinuclear antibodies. The sera were diluted $1: 10$ in phosphate buffered saline $(0.01 \mathrm{M}$ phosphate; $\mathrm{pH} 7 \cdot 2)$ before testing.

IMMUNOFLUORESCENT ASSAY FOR

ANTINUCLEAR ANTIBODIES

The investigations were performed according to the method of Feltkamp and van Rossum (1968), but the washing before incubation with the mouse serum was avoided. UV-irradiated and non-irradiated unfixed rat liver cryostat sections $(4 \mu)$ were used as nuclear substrate, and a rabbit anti-mouse IgG serum, conjugated to fluorescein isothiocyanate (The and Feltkamp, 1970), was used as a fluorescent reagent. Irradiation of the sections was obtained by exposure to a Germicidal lamp for $5 \mathrm{~min}$. at a distance of $10 \mathrm{~cm}$. 

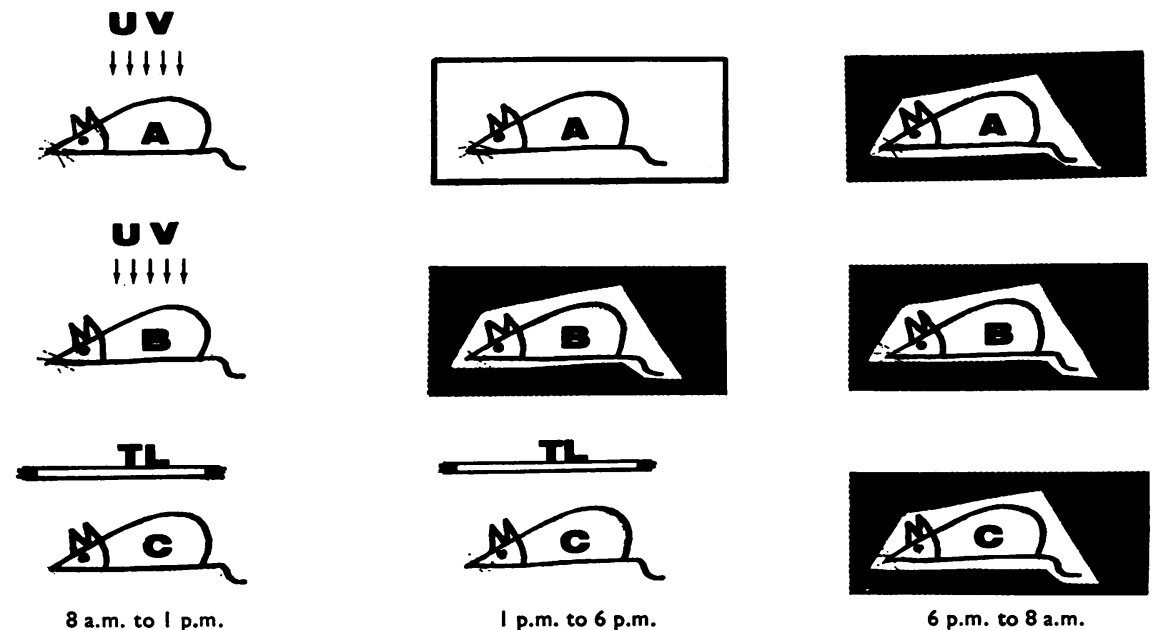

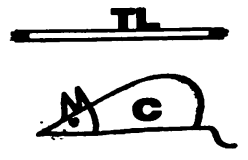

I p.m. to 6 p.m.

FIGURE Irradiation scheme.

\section{Results}

From Table I, which gives antinuclear antibody (ANA) titres of the first experiment, it may be seen that mice in Group B, receiving a daily treatment of UV light and darkness, developed ANA earlier, in higher frequencies, and in higher titres than mice from Group A, which were UV irradiated but afterwards kept in daylight, and also than those from Group C (controls). Results with irradiated and nonirradiated sections were identical.

Table I Reciprocal titres of antinuclear antibodies in sera from twelve female Swiss mice

Group A Irradiated daily with UV for 5 hrs and afterwards exposed to daylight

Group B Irradiated in the same way and kept in darkness afterwards

Group C untreated controls

\begin{tabular}{|c|c|c|c|}
\hline Mice & $\begin{array}{l}\text { Before } \\
\text { irradiation }\end{array}$ & After 6 wks & After $8 w k s$ \\
\hline $\begin{array}{ll} & 1 \\
2 & \\
& 3 \\
& 4\end{array}$ & $\begin{array}{l}z \\
\overline{-}\end{array}$ & $\begin{array}{l}\overline{10} \\
-\end{array}$ & $\begin{array}{l}-20 \\
20 \\
-\end{array}$ \\
\hline 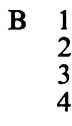 & $\begin{array}{l}E \\
z\end{array}$ & $\begin{array}{l}-\overline{10} \\
80 \\
20\end{array}$ & $\begin{array}{r}80 \\
80 \\
\geqslant 160 \\
40\end{array}$ \\
\hline $\begin{array}{ll}\text { C } & 1 \\
& 2 \\
& 3 \\
& 4\end{array}$ & $\frac{\overline{10}}{-}$ & $\frac{\overline{10}}{-}$ & $\frac{\overline{40}}{40}$ \\
\hline
\end{tabular}

With the results obtained in the second experiment (Table II) the preliminary findings were confirmed, viz.:

(1) The UV-irradiated animals developed a higher ANA frequency than the non-irradiated animals $(\mathrm{P}<0.05)$.

(2) There is a lower ANA frequency in the male mice which were kept in daylight after irradiation than in those kept in darkness $(P<0 \cdot 01)$. This effect was not significant in females.

(3) There is a female preponderance in number of mice developing ANA in the irradiated group $(\mathrm{P}<0 \cdot 05)$.

Table II ANA incidence in $U V$ and daylighttreated mice $(A), U V$ and darkness-treated mice $(B)$, and control mice $(C)$

\begin{tabular}{|c|c|c|c|c|}
\hline \multicolumn{2}{|c|}{ Mice } & \multirow{2}{*}{$\begin{array}{l}\begin{array}{l}\text { Before } \\
\text { irradiation }\end{array} \\
1 / 32\end{array}$} & \multirow{2}{*}{$\frac{\text { After } 4 w k s}{3 / 31}$} & \multirow{2}{*}{$\begin{array}{c}\text { After } 6 \text { wks } \\
9 / 32\end{array}$} \\
\hline $\bar{A}$ & Total & & & \\
\hline & $\begin{array}{l}\text { Males } \\
\text { Females }\end{array}$ & $\begin{array}{l}0 / 16 \\
1 / 16\end{array}$ & $\begin{array}{l}1 / 15 \\
2 / 16\end{array}$ & $\begin{array}{l}1 / 16 \\
8 / 16\end{array}$ \\
\hline \multirow[t]{2}{*}{ B } & Total & $0 / 32$ & $5 / 26$ & $17 / 32$ \\
\hline & $\begin{array}{l}\text { Males } \\
\text { Females }\end{array}$ & $\begin{array}{l}0 / 16 \\
0 / 16\end{array}$ & $\begin{array}{l}1 / 11 \\
4 / 15\end{array}$ & $\begin{array}{l}8 / 16 \\
9 / 16\end{array}$ \\
\hline \multirow[t]{2}{*}{$\mathrm{C}$} & Total & $2 / 32$ & $2 / 29$ & $3 / 28$ \\
\hline & $\begin{array}{l}\text { Males } \\
\text { Females }\end{array}$ & $\begin{array}{l}1 / 16 \\
1 / 16\end{array}$ & $\begin{array}{l}1 / 15 \\
1 / 14\end{array}$ & $\begin{array}{l}1 / 14 \\
2 / 14\end{array}$ \\
\hline
\end{tabular}




\section{Discussion}

A possible explanation for the UV-induced ANA may be the involvement of photoproducts of DNA. Recently it was shown that UV-irradiation of mice induces DNA alterations in the skin and subjacent layers (Tan and Stoughton, 1969) and we were able to confirm these observations. It could very well be that UV-DNA, which is known to be a strong antigen (Levine and other, 1966; Levine and Stollar, 1968), gives rise to the production of autoantibodies that cross-react with normal non-irradiated DNA. From this point of view there is a fair correlation with the events that happen after immunization of rabbits with UV-DNA. Our results, which were identical when using irradiated and non-irradiated sections in the immunofluorescent technique, support this hypothesis. We therefore suppose that the UV irradiation induces antibodies against UV-DNA which cross-react with normal DNA, thus forming antinuclear antibodies. These resulta are suggestive for the hypothesis that UV irradiatioh acts as a trigger mechanism in latent SLE. The results might also explain the exacerbation of SLE after exposure to sunlight.

The observed female preponderance is in accordance with that found in idiopathic autoimmune disease and has also been observed in iatrogenic autoimmune phenomena (Cannat and Seligmann, 1968).
It might be supposed that the mice which were daily kept in the dark after the UV treatment received a stronger antigenic stimulation than those which were kept in daylight. The most likely explanation for the possibly smaller quantity of UV-DNA in these mice is the assumption of a photorepair mechanism in these animals. Such a mechanism would repair the UV-induced damage to DNA, thus eliminating part or all of the antigen available for immunization.

Studies concerning the influence of these exogenous factors on the DNA molecule and their consequences for SLE pathology are in progress.

\section{Summary}

Swiss mice irradiated daily with UV light developed antinuclear antibodies (ANA) as demonstrated by the immunofluorescent technique. There was a preponderance of the ANA frequencies in female mice. A difference in ANA frequencies was found when the mice were divided each day after UV irradiation into two groups, one being kept in normal daylight and one in total darkness. The second group showed a higher incidence of ANA. This might suggest the presence of a photorepair mechanism in these mammals.

We wish to thank Prof. Dr. P. Borst and Dr. T. E. W. Feltkamp for their critical support.

\section{References}

Cannat, A., and Seligmann, M. (1968) Clin. exp. Immunol., 3, 99 (Induction by isoniazid and hydrallazine of antinuclear factors in mice).

Cleaver, J. E., AND Painter, R. B. (1968) Biochem. biophys. Acta, 161, 552 (Evidence for repair replication of HeLa cell DNA damaged by ultraviolet light).

Cook, J. S., AND ReGAN, J. D. (1969) Nature (Lond.), 223, 1066 (Photoreactivation and photoreactivating enzyme activity in an order of mammals (Marsupialia)).

Dubors, E. L. (1966) 'Lupus Erythematosus'. McGraw-Hill, New York.

FeltKamp, T. E. W., and van Rossum, A. L. (1968) Clin. exp. Immunol., 3, 1 (Antibodies to salivary duct cells, and other autoantibodies, in patients with Sjögren's syndrome and other idiopathic autoimmune diseases).

Freeman, R. G., KnoX, J. M., and Owens, D. W. (1969) Arch. Derm. (Chicago), 100, 677 (Cutaneous lesions of lupus erythematosus induced by monochromatic light).

- Troll, D., AND KNo\$, J. M. (1968) Texas Rep. Biol. Med., 26, 309 (Photoreactivation from the efiects of $300 \mathrm{NM}$ and $250 \mathrm{NM}$ monochromatic ultraviolet radiation in albino mouse skin).

Levine, L., Seaman, E., Hammerschlag, E., and Van Vunakis, H. (1966) Science, 153, 1666 (Antibodies to photoproducts of deoxyribonucleic acids irradiated with ultraviolet light).

- - and Stollar, D. (1968) In 'Progress in Allergy', vol. 12. Karger, Basel.

Setlow, R. B. (1968) 'The photochemistry, photobiology, and repair of polynucleotides', in 'Progress in Nucleic Acid Research and Molecular Biology', ed. J. N. Davidson and W. E. Cohn, vol. 8. Academic Press, New York.

Tan, E. M., and Stoughton, R. B. (1969) Proc. nat. Acad. Sci., 62, 708 (Ultraviolet light alteration of cellular deoxyribonucleic acid in vivo).

The, T. H., AND FeltKamp, T. E. W. (1970) Immunology, 18, 875 (Conjugation of fluorescein isothiocyanate to antibodies. II. A reproducible method). 